\title{
LAND SNAILS OF BOZCAADA ISLAND, TURKEY WITH ANATOMICAL AND DISTRIBUTIONAL NOTES FOR SEVERAL SPECIES
}

\author{
AYDIN ÖRSTAN ${ }^{1 *}$, PANAYOTIS OVALIS ${ }^{2}$ \\ ${ }^{1}$ Section of Mollusks, Carnegie Museum of Natural History, Pittsburgh, Pennsylvania, 15213, U.S.A. \\ (e-mail: anothersnail@hotmail.com); (1) https://orcid.org/0000-0002-2167-5694 \\ ${ }^{2}$ Agisilaou 37-39, Tzitzifies/Kallithea, 17674, Athens, Greece; (i) https://orcid.org/0000-0002-9214-9616 \\ * corresponding author
}

\begin{abstract}
A survey of the land snails of Bozcaada, a small island in the Aegean Sea near the northwest coast of Turkey, found 30 species. Mediterranea depressa (Sterki) was recorded for the first time in Turkey. Five species in the family Enidae were found on the island; the most unexpected one was Chondrus tournefortianus (Férussac) outside of its previously known range. The conchological and anatomical characteristics of the specimens identified as Meijeriella cf. raynevaliana (Bourguignat) are given and the associated taxonomic issues are briefly discussed. Anatomies of Monacha claustralis (Rossmässler), Orculella critica (Pfeiffer) and Oxychilus cyprius (Pfeiffer) are also presented. As expected, the land snail faunas of Bozcaada, the nearby islands of Gökçeada and Limnos and the mainland Turkey share some species. Some of the differences in the species compositions of these areas may be explained as results of human-mediated introductions.
\end{abstract}

KEYWORDS: Pulmonata; Enidae; insular biodiversity; introduced species

\section{INTRODUCTION}

Bozcaada (Tenedos in Greek) is a small island (approximately $37 \mathrm{~km}^{2}$ ) in the Aegean Sea about 5 $\mathrm{km}$ off the coast of the mainland Turkey. The island's name derives from the Turkish word "boz", the colour of bare soil, in reference to the appearance of the island from far away due to the lack of significant forest cover on it. There are just a few pine groves on the island; the largest of these, near the western tip of the island, covers only about $1.5 \mathrm{~km}^{2}$. The only town on the island, also called Bozcaada, is on the northeast corner facing the mainland. There are numerous touristic developments along the eastern and southern coasts of the island, while the northern coast, exposed to the northerly winds, remains mostly undeveloped.

The island is mostly flat; the highest hill, Göztepe, rises to an elevation of only about $180 \mathrm{~m}$. Most of the western half of the island is limestone and limestone conglomerate and the southeastern corner is marble. The areas immediately to the west and south of the town of Bozcaada consist of volcanic rocks with some limestone around Göztepe (ERGUVANLI 1955). Large outcrops and cliffs, which often provide good habitats for land snails, are absent on the island. Nevertheless, the presence of calcareous base rocks indicates that the land snail fauna of the island would not be depauperate. Moreover, the closeness of the island to the mainland Turkey as well as to the islands of Gökçeada and Limnos suggests that zoogeographically revealing information may be gained from the composition of the land snail fauna of the island. However, we found only three published records of land snails from Bozcaada: Albinaria discolor by NORDSIECK (1999), Orculella critica by SCHÜTT (2010) and Monacha claustralis by HAUSDORF (2000).

To remedy this knowledge gap in the distributions of the land snails of northwest Turkey, we carried out a land snail survey that covered most of the island of Bozcaada. In this paper we present the results of our survey and discuss the noteworthy findings. 


\section{MATERIAL AND METHODS}

Collections were done in the summers of 2019 and 2021. In addition to the visual search conducted at each site, soil samples were taken at 10 of the stations. These samples were sieved and sorted for smaller shells. The finest sieve was $0.5 \mathrm{~mm}$ mesh. Slugs were excluded from the survey. Four species were identified by dissection. In the descriptions of genitalia, the term distal is relative to the ovotestis. Species names follow MollusCaBASE (2021) except otherwise noted. The relevant literature data for selected species have been included in the Results section to facilitate the analysis of our finds. Voucher specimens for six of the species collected on Bozcaada have been deposited in the Carnegie Museum of Natural History, Pittsburgh, PA, U.S.A. (CM 177533-177538).

The following list gives the description and coordinates of the 20 collection stations (Fig. 1). The prefix $\mathrm{Bz}$ that was used to distinguish the Bozcaada locality numbers in the personal records of the first author is retained here to prevent any future confusion.

Bz1: Fort in the town of Bozcaada, $39^{\circ} 50^{\prime} 10.7^{\prime \prime} \mathrm{N}$, $26^{\circ} 04^{\prime} 20.6^{\prime \prime} \mathrm{E}$,

$\mathrm{Bz2}$ : Old stone wall on hillside west of windmills, north of town, $39^{\circ} 50^{\prime} 21.5^{\prime \prime} \mathrm{N}, 26^{\circ} 03^{\prime} 57.2^{\prime \prime} \mathrm{E}$,

Bz3: Field across from Corvus Winery, $39^{\circ} 48^{\prime} 18^{\prime \prime} \mathrm{N}$, 260.'39"E,

Bz4: North slope of Göztepe Hill northwest of town, $39^{\circ} 50^{\prime} 42^{\prime \prime} \mathrm{N}, 26^{\circ} 03^{\prime} 03.6^{\prime \prime} \mathrm{E}$,
Bz5: Ayazma Point on south coast, $39^{\circ} 48^{\prime} 46.8^{\prime \prime} \mathrm{N}$, 260' 16.2"E,

Bz6: Sandy slopes above coast on north shore, $39^{\circ} 50^{\prime} 38.4^{\prime \prime} \mathrm{N}, 26^{\circ} 01^{\prime} 01.2^{\prime \prime} \mathrm{E}$,

Bz7: Calcareous rocks along field, $39^{\circ} 49^{\prime} 55.2^{\prime \prime} \mathrm{N}$, $26^{\circ} 00^{\prime} 25.2^{\prime \prime} \mathrm{E}$

Bz8: Ruins of old cottage, $39^{\circ} 50^{\prime} 28.3^{\prime \prime} \mathrm{N}, 25^{\circ} 59^{\prime} 46.7^{\prime \prime} \mathrm{E}$,

Bz9: Ruins of old lighthouse, westernmost point of island (Polente Point), 3950'19.3"N, 25 57'46.1"E,

Bz10: Rocky hill (Bizan Tepe), southwest of town, $39^{\circ} 49^{\prime} 15.6^{\prime \prime} \mathrm{N}, 26^{\circ} 03^{\prime} 24.8^{\prime \prime} \mathrm{E}$,

Bz11: Rocks above Habbele Point, 3949'08.4"N, 2559'02.4"E,

Bz12: Vineyards and rocky fields, Sarayağa District, $39^{\circ} 49^{\prime} 33.6^{\prime \prime} \mathrm{N}, 26^{\circ} 01^{\prime} 01.2^{\prime \prime} \mathrm{E}$,

Bz13: Rocks above southernmost tip of island. $39^{\circ} 47^{\prime} 16.8^{\prime \prime} \mathrm{N}, 26^{\circ} 03^{\prime} 10.8^{\prime \prime} \mathrm{E}$,

Bz14: Rocky meadow at Ayana District, $39^{\circ} 48^{\prime} 07.2^{\prime \prime} \mathrm{N}$, 2602'45.6"E,

Bz15: Calcareous rocks on slope above road, $39^{\circ} 49^{\prime} 18.8^{\prime \prime} \mathrm{N}, 25^{\circ} 59^{\prime} 51.4^{\prime \prime} \mathrm{E}$,

Bz16: Calcareous boulders along road, $39^{\circ} 47^{\prime} 41.6^{\prime \prime} \mathrm{N}$, 260.'00.7"E,

Bz17: Calcareous rocks along orchard, $39^{\circ} 50^{\prime} 21.8^{\prime \prime} \mathrm{N}$, $26^{\circ} 00^{\prime} 55.8^{\prime \prime} \mathrm{E}$

Bz18: Calcareous rocks around Tuzburnu Lighthouse, $39^{\circ} 48^{\prime} 00.4^{\prime \prime} \mathrm{N}, 26^{\circ} 04^{\prime} 51.6^{\prime \prime} \mathrm{E}$,

Bz19: Boulders by dirt road to windmills, $39^{\circ} 50^{\prime} 15^{\prime \prime} \mathrm{N}$, 260.'06.6"E,

Bz20: Pine groves on hillside west of town, $39^{\circ} 50^{\prime} 11^{\prime \prime} \mathrm{N}$, 260.'01.2"E.

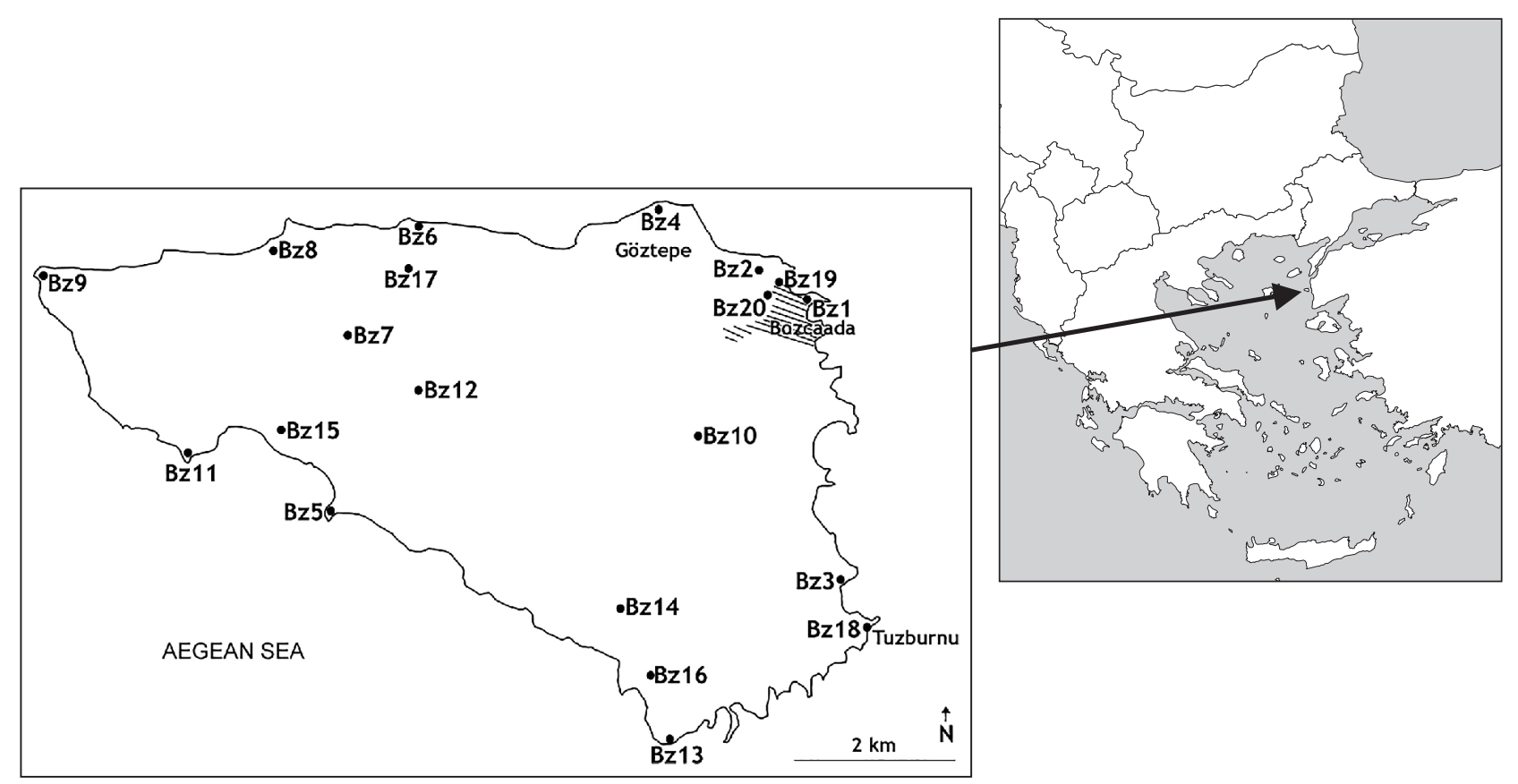

Fig. 1. Locations of collection stations on Bozcaada 


\section{RESULTS}

Our survey found 30 species of land snails (Table 1). We consider five of those species, Albinaria discolor, Cantareus apertus, Cernuella virgata, Chondrus tournefortianus and Eobania vermiculata, not native to the island. As we discuss below, the presence of these species on the island is most likely due to introductions by humans. The most widespread species on the island in terms of the number of collection stations were C. virgata, E. vermiculata and Monacha claustralis. E. vermiculata was especially abundant at some localities. For example, in the fort in the town of Bozcaada (station Bz1), we collected approximately 120 empty E. vermiculata shells in an enclosure that was about $10 \mathrm{~m} \times 10 \mathrm{~m}$. Below are additional remarks on some of the species found during the survey.
Albinaria discolor (Pfeiffer, 1846): The presence of this species on Bozcaada was first noted by NORDSIECK (1999), but SCHÜTT (2010) repeatedly identified the Bozcaada Albinaria species as A. caerulea maculata (Rossmässler) in his book including the final edition. The comparison of specimens from Bozcaada with specimens of $A$. caerulea maculata from Ephesus, Turkey (ÖRSTAN 2001) highlights the differences between them (Figs 2-3). In Bozcaada specimens the protoconch is brown, the dorsal keel is missing and the lower whorls of the teleoconch are mostly smooth, while in A. caerulea maculata the protoconch is bluish, the dorsal keel is present and the teleoconch is distinctly ribbed. The Bozcaada Albinaria specimens are clearly not $A$. caerulea; they indeed match the

Table 1. Land snail species collected on Bozcaada and the stations where each was found (for station designation see: Material and methods, and Fig. 1)

\begin{tabular}{|c|c|}
\hline Species & Localities \\
\hline Albinaria discolor (Pfeiffer) & $\mathrm{Bz} 1, \mathrm{Bz} 3, \mathrm{Bz} 5, \mathrm{Bz} 13, \mathrm{Bz} 15, \mathrm{Bz} 18$ \\
\hline Cantareus apertus (Born) & $\mathrm{Bz} 2, \mathrm{Bz} 4, \mathrm{Bz} 10, \mathrm{Bz} 19$ \\
\hline Caracollina lenticula (Michaud) & $\mathrm{Bz} 2, \mathrm{Bz} 4$ \\
\hline Cecilioides acicula (O. F. Müller) & $\mathrm{Bz} 1, \mathrm{Bz} 16, \mathrm{Bz} 17$ \\
\hline Cernuella virgata (Da Costa) & $\begin{array}{l}\mathrm{B} z 1, \mathrm{Bz} 2, \mathrm{~B} z 3, \mathrm{~B} z 4, \mathrm{Bz} 5, \mathrm{~B} z 6, \mathrm{~B} z 7, \mathrm{Bz} 9, \mathrm{Bz} 10, \mathrm{Bz} 11, \mathrm{~B} z 12, \mathrm{Bz} 13, \mathrm{~B} z 14, \mathrm{~B} z 15 \\
\mathrm{~B} z 16, \mathrm{~B} z 19\end{array}$ \\
\hline Chondrus tournefortianus (Férussac) & $\mathrm{Bz} 9$ \\
\hline Eobania vermiculata (O. F. Müller) & $\begin{array}{l}\mathrm{Bz} 1, \mathrm{Bz} 2, \mathrm{Bz} 3, \mathrm{Bz} 4, \mathrm{~B} z 5, \mathrm{Bz} 6, \mathrm{Bz} 7, \mathrm{Bz} 8, \mathrm{Bz} 9, \mathrm{~B} z 10, \mathrm{~B} z 11, \mathrm{Bz} 12, \mathrm{~B} z 13, \mathrm{~B} z 14 \\
\mathrm{~B} z 15, \mathrm{~B} z 16, \mathrm{~B} z 17, \mathrm{~B} z 18\end{array}$ \\
\hline Granopupa granum (Draparnaud) & $\mathrm{Bz} 3, \mathrm{~B} z 4, \mathrm{~B} z 5, \mathrm{Bz} 7, \mathrm{Bz} 11, \mathrm{~B} z 13, \mathrm{Bz} 15, \mathrm{Bz} 17, \mathrm{Bz} 18$ \\
\hline Helix lucorum Linnaeus & $\mathrm{Bz} 2, \mathrm{Bz} 4$ \\
\hline Helix nucula Mousson & $\mathrm{Bz} 2, \mathrm{Bz} 3, \mathrm{Bz} 5, \mathrm{Bz} 7, \mathrm{Bz} 8, \mathrm{Bz} 9, \mathrm{Bz} 10, \mathrm{Bz} 13$ \\
\hline Jaminia loewii (Philippi) & $\mathrm{Bz} 4$ \\
\hline Lauria cylindracea (Da Costa) & $\mathrm{Bz} 5, \mathrm{Bz} 8$ \\
\hline Mastus rossmaessleri (Pfeiffer) & $\mathrm{Bz} 2, \mathrm{Bz} 4$ \\
\hline Mediterranea depressa (Sterki) & $\mathrm{Bz} 3$ \\
\hline Mediterranea hydatina (Rossmässler) & $\mathrm{Bz} 11, \mathrm{Bz} 12, \mathrm{Bz} 14, \mathrm{Bz} 15$ \\
\hline Meijeriella cf. raynevaliana (Bourguignat) & $\mathrm{Bz} 4, \mathrm{Bz} 10, \mathrm{Bz} 20$ \\
\hline Metafruticicola redtenbacheri (Pfeiffer) & $\mathrm{Bz} 2, \mathrm{Bz} 16$ \\
\hline Monacha claustralis (Rossmässler) & $\begin{array}{l}\mathrm{Bz} 1, \mathrm{~B} z 2, \mathrm{~B} z 3, \mathrm{~B} z 4, \mathrm{~B} z 5, \mathrm{~B} z 6, \mathrm{Bz} 7, \mathrm{Bz} 9, \mathrm{~B} z 10, \mathrm{~B} z 11, \mathrm{~B} z 13, \mathrm{Bz} 14, \mathrm{~B} z 15, \mathrm{~B} z 17 \\
\mathrm{Bz} 18\end{array}$ \\
\hline Monacha ocellata (Roth) & $\mathrm{Bz} 1, \mathrm{Bz} 2, \mathrm{Bz} 3$ \\
\hline Orculella critica (Pfeiffer) & $\mathrm{Bz} 3, \mathrm{Bz} 5, \mathrm{Bz} 6, \mathrm{Bz} 12, \mathrm{Bz} 17$ \\
\hline Oxychilus cyprius (Pfeiffer) & $\mathrm{Bz} 3$ \\
\hline Pleurodiscus balmei (Potiez et Michaud) & $\mathrm{Bz} 2$ \\
\hline Pseudojaminia seductilis (Rossmässler) & $\mathrm{Bz} 3, \mathrm{Bz} 5, \mathrm{Bz} 6, \mathrm{Bz} 7, \mathrm{Bz} 11, \mathrm{Bz} 12, \mathrm{Bz} 13, \mathrm{Bz} 14, \mathrm{Bz} 15, \mathrm{Bz} 16, \mathrm{Bz} 17, \mathrm{Bz} 18$ \\
\hline Pyramidula pusilla (Vallot) & $\mathrm{Bz} 7, \mathrm{Bz} 8, \mathrm{Bz} 12$ \\
\hline Trochoidea pyramidata (Draparnaud) & $\mathrm{Bz} 3, \mathrm{Bz} 8, \mathrm{Bz} 9, \mathrm{Bz} 10, \mathrm{Bz} 15, \mathrm{Bz} 18$ \\
\hline Truncatellina cylindrica (Férussac) & $\mathrm{Bz} 8$ \\
\hline Xeropicta krynickii (Krynicki) & $\mathrm{Bz} 3, \mathrm{Bz} 4, \mathrm{Bz} 5, \mathrm{Bz} 7, \mathrm{Bz} 8, \mathrm{Bz} 18$ \\
\hline Vallonia pulchella (O. F. Müller) & $\mathrm{Bz} 1$ \\
\hline Vitrea contracta (Westerlund) & $\mathrm{Bz} 16$ \\
\hline Vitrea riedeli Damjanov et Pintér & $\mathrm{Bz} 5, \mathrm{Bz} 17$ \\
\hline
\end{tabular}




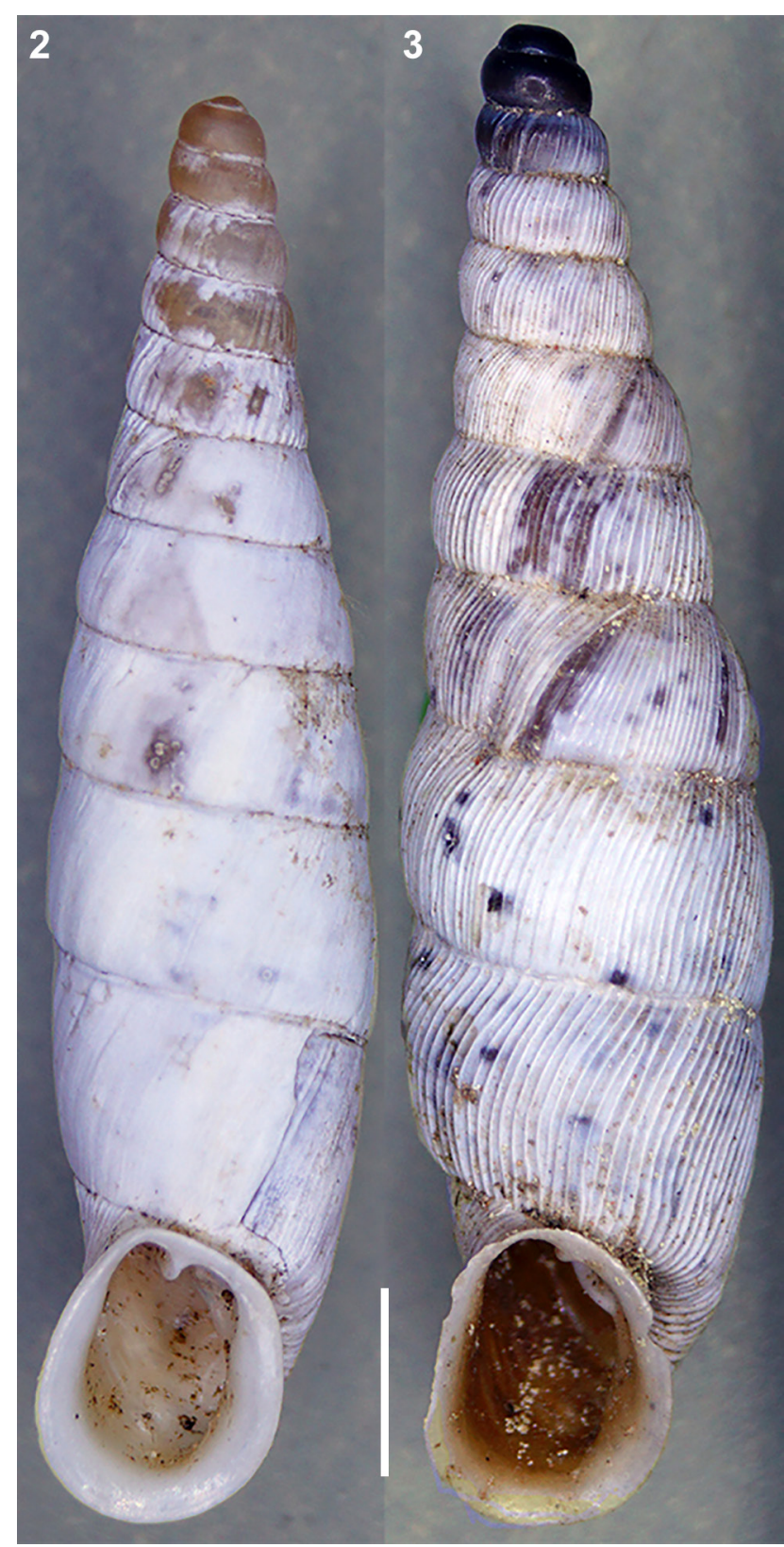

Figs 2-3. 2 - Albinaria discolor from Bozcaada (shell height $15.2 \mathrm{~mm}) ; 3$ - A. caerulea maculata from Ephesus, Turkey (shell height $16.0 \mathrm{~mm}$ ). Scale bar $2 \mathrm{~mm}$

description of $A$. discolor (WeLTER-SCHULTES 2012). NORDSIECK (1999) thought that $A$. discolor had probably been introduced to Bozcaada. The type locality of A. discolor is the Island of Kithira off the southern coast of Peloponnese, Greece. The species is also present in the eastern Peloponnese, southern Attica and several nearby islands (WELTER-SCHULTES 2012). Bozcaada constitutes a disjunct locality (the species has not been recorded on mainland Turkey) which supports the hypothesis that $A$. discolor was introduced to the island. We found $A$. discolor on the walls of the large fort in town and at two additional localities along the southern coast of the island where there were calcareous rocks. The most likely point of introduction is the fort that occupies a prominent position in the harbour and which has a long and somewhat uncertain history. It is believed to have been built in its present form by the Ottomans during the 15th century in place of an earlier military installation and restored many times over the following centuries (ACIOĞLU 2015). The present walls of the fort contain both calcareous and non-calcareous rocks reflecting its long history of restorations. The colonies of $A$. discolor present in the south of the island are likely to be secondary introductions presumably with material from the fort.

Chondrus tournefortianus (Férussac, 1821): We found only two shells of this species (Fig. 4) in the ruins located at the westernmost tip of island known as Polente (or Ponente) Point. The ruins are of the former lighthouse that was in existence at least as early as the 1910s (ANONYMOUS 1916). The lack of C. tournefortianus elsewhere on the island suggests that the species may have been introduced to the locality from the mainland over a century ago perhaps when the lighthouse was built. This is the westernmost record of this species from Turkey. Its previous records were primarily from central-northern Turkey extending to the Istanbul area with a seemingly disjunct spot in coastal Bulgaria (WELTER-SCHULTES 2012). Our record from Bozcaada constitutes another disjunct locality. Four other species of the family Enidae were also found on the island (Figs 5-8).

Meijeriella cf. raynevaliana (Bourguignat, 1855): We have identified the tall and slim enid specimens collected on Bozcaada as the same species as BOURGUIGNAT's (1855) Bulimus raynevalianus (Fig. 6). The explanation of our identification is as follows. The type locality of $B$. raynevalianus was the vicinity of Gelibolu on the mainland Turkey approximately $80 \mathrm{~km}$ (as the crow flies) northeast of Bozcaada. BOURGUIGNAT's (1855) specimens of B. raynevalianus were $15-17 \mathrm{~mm}$ long and $5 \mathrm{~mm}$ wide and had a small tubercule on the palatal lip. Our specimens from Bozcaada range in height from $12.1 \mathrm{~mm}$ to $17.0 \mathrm{~mm}$ with diameters of 3.4 to $4.3 \mathrm{~mm}$. Although the heights of the Bozcaada shells are comparable to those of BOURGUIGNAT's (1855) specimens of B. raynevalianus, they are somewhat narrower. A slight swelling on the palatal lip is also present on our shells in agreement with BOURGUIGNAT's (1855) description.

FORCART (1940) transferred both B. raynevalianus and the smaller B. frivaldskyi Pfeiffer to the genus Ena, and, despite having noted the presence of conchological differences between their shells that could have justified their retention as separate species, he treated raynevaliana as a subspecies of the taxonomically older Ena frivaldskyi. The type locality of Bulimus frivaldskyi was Bursa in Turkey (about $260 \mathrm{~km}$ east of the coast facing Bozcaada). The six specimens from Bursa that FORCART (1940) examined were 11.2$14.5 \mathrm{~mm}$ long and $3.7-4.7 \mathrm{~mm}$ wide. 
No anatomical information was available for either taxon until GÜMÜș \& NEUBERT (2012) presented the description of the genitalia of a specimen from Troy that they identified as Meijeriella frivaldskyi. The placement of frivaldskyi in Meijeriella was justified by the insertion of the penile retractor at the distal end of the epiphallus and by the lack of a penile appendix, these being in agreement with the description of the genus as established for the type species $M$. canaliculata (BANK 1985). In comparison, in Ena the penis has an appendix and the retractor inserts on the penis (SCHILEYKO 1998, HAUSDORF 2001). Moreover, without giving an explanation, GÜMÜș \& NEUBERT (2012) considered B. raynevalianus a junior synonym of $M$. frivaldskyi.

We dissected two specimens from Bozcaada. Their genitalia show two differences in comparison to the genitalia of both $M$. frivaldskyi and $M$. canaliculata. First, the vas deferens of the Bozcaada specimens enlarges over a span of about a millimetre before en- tering the epiphallus next to the flagellum (Fig. 9: arrow head). This enlargement was not mentioned by GÜMÜș \& NEUBERT (2012) or BANK (1985) nor is it obvious in their drawings of the genitalia. Second, the retractor of the Bozcaada specimens attaches not to the epiphallus but to the penis itself very close to the attachment point of the epiphallus (Fig. 9).

Taking into account the conchological and anatomical differences we have presented here, we are disregarding the synonymy proposed by GÜMÜș \& NEUBERT (2012) and identifying the Bozcaada specimens tentatively as Meijeriella raynevaliana. Actually, if we go by the present diagnosis of Meijeriella (BANK 1985), our specimens are not Meijeriella. The diagnosis of Meijeriella reads in part (BANK 1985): "Musculus retractor am distalen Teil des Epiphallus (also nicht am proximalen Teil des Penis)". Instead, they may be placed in the genus Borlumastus the diagnosis of which specifies that the retractor attaches to the penis (ÖRSTAN \& YILDIRIM 2004). To confirm (or

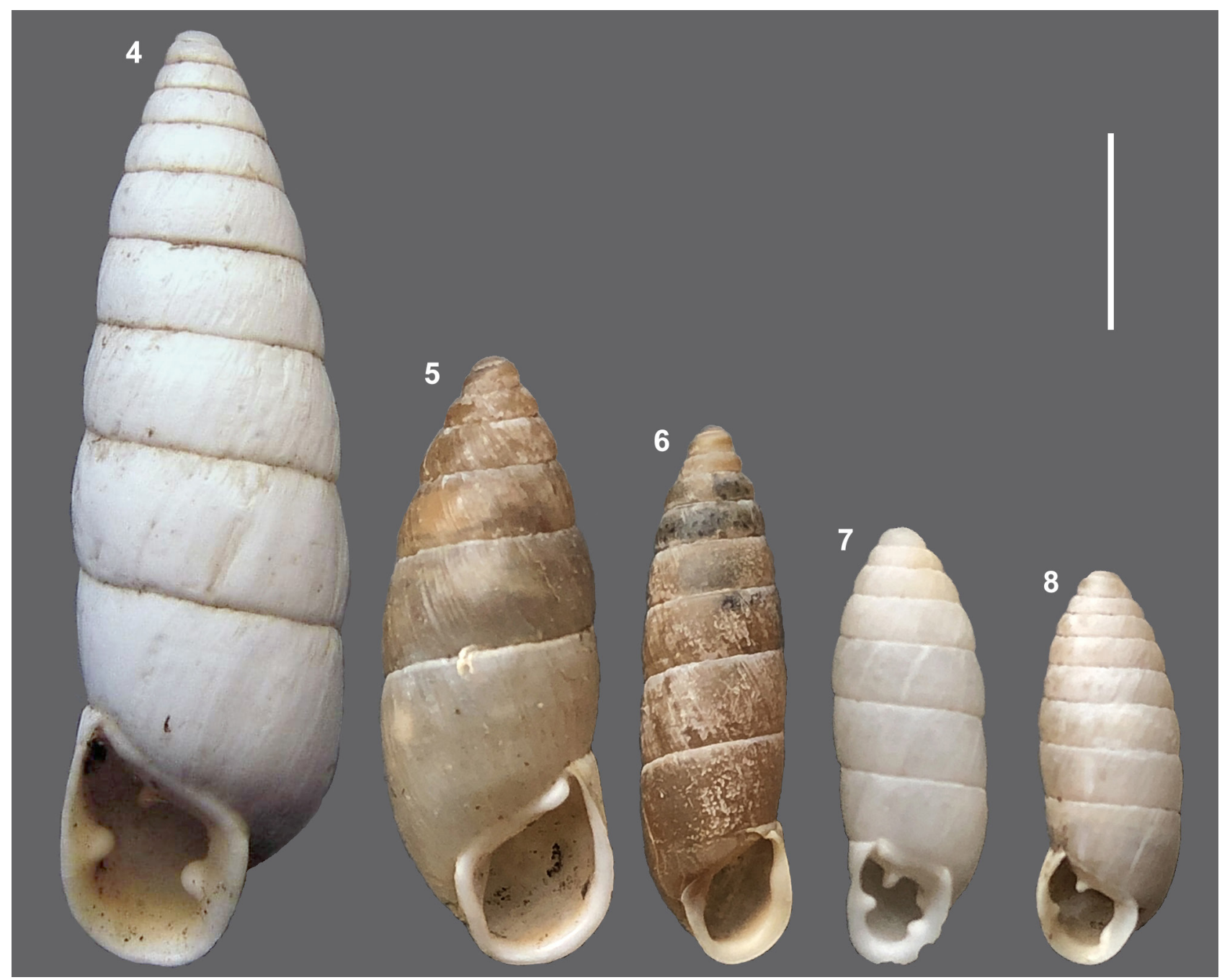

Figs 4-8. Enid species of Bozcaada (height of each shell in parentheses): 4 - Chondrus tournefortianus (23.7 mm), 5 - Mastus rossmaessleri $(15.3 \mathrm{~mm}), 6$ - Meijeriella cf. raynevaliana $(13.9 \mathrm{~mm}), 7$ - Jaminia loewii $(11.3 \mathrm{~mm}), 8$ - Pseudojaminia seductilis $(10.1 \mathrm{~mm})$. Scale bar $5 \mathrm{~mm}$ 

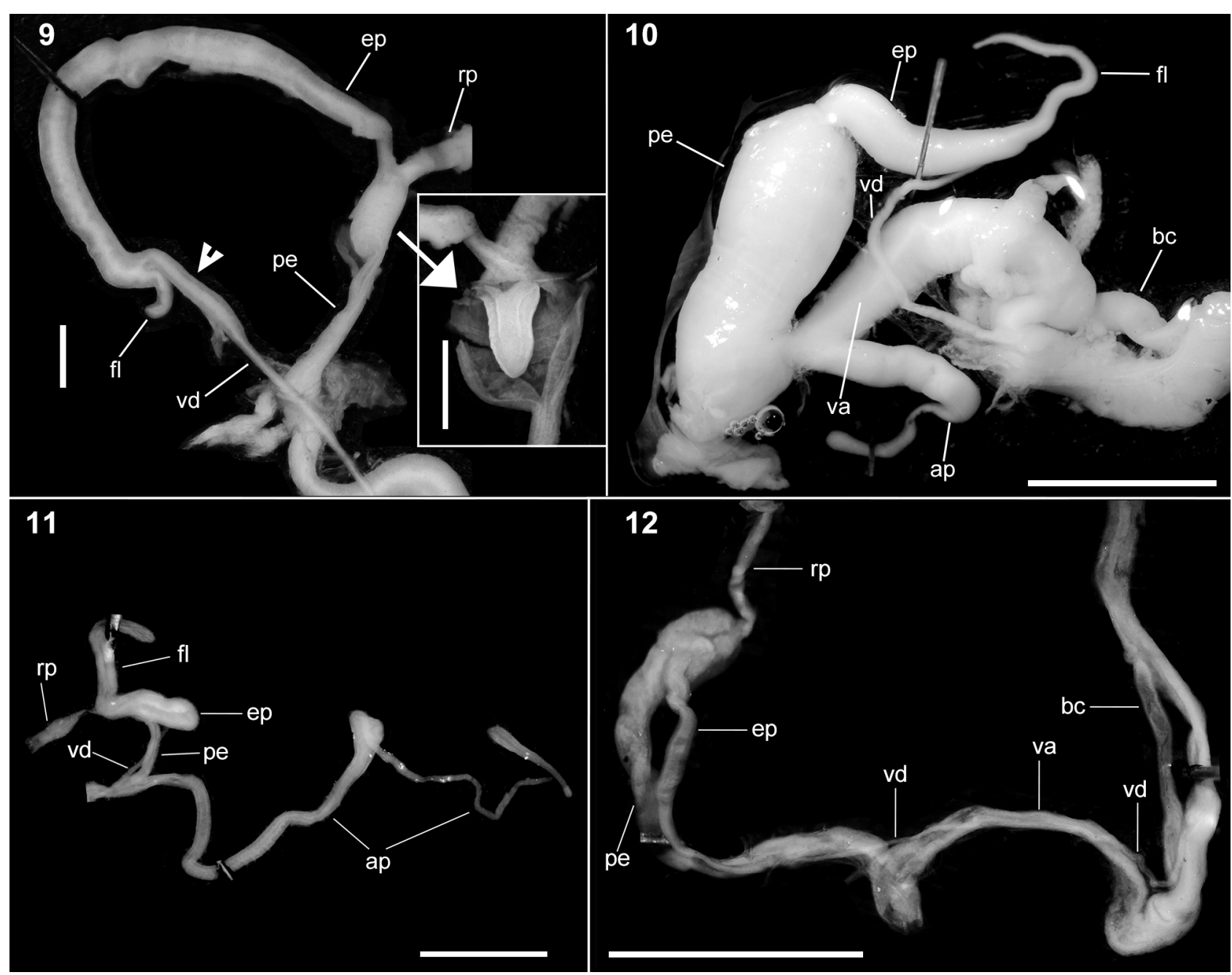

Figs 9-12. Anatomies of selected Bozcaada species: 9 - distal male genitalia of Meijeriella cf. raynevaliana (inset: opened penis showing verge); 10 - genitalia of Monacha claustralis; 11 - distal male genitalia of Orculella critica; 12 - genitalia of Oxychilus cyprius. Abbreviations: ap - appendix; bc - bursa copulatrix; ep - epiphallus; fl - flagellum; pe - penis; $\mathrm{rp}$ - retractor of penis; va - vagina; vd - vas deferens. Scale bars $0.5 \mathrm{~mm}$ (9), $3 \mathrm{~mm}$ (10), $1 \mathrm{~mm}$ (11) and $2 \mathrm{~mm}$ (12)

to dismiss) our taxonomic opinion, we are planning to search for specimens in the near future around Gelibolu, the type locality of B. raynevalianus.

Metafruticicola redtenbacheri (Pfeiffer, 1856): Our record of this species from Bozcaada is its northernmost occurrence in Turkey, although it is present at localities further north in Greece (BANK et al. 2013: fig. 37).

Monacha claustralis (Rossmässler, 1834): We identified this species from its genitalia (Fig. 10). This species is conchologically identical to M. cartusiana (O. F. Müller) (HAUSDORF 2000), but the two species differ in their genitalia, the primary difference being the presence of a vaginal sac in M. cartusiana that is missing in M. claustralis (Fig. 10) (HAUSDORF 2000, PIEŃKOWSKA et al. 2018). M. liebegottae Hausdorf, the type locality of which is the island of Gökçeada situated roughly $35 \mathrm{~km}$ north of Bozcaada, also has a somewhat similar shell, but it differs from M. claustralis in the presence of an appendix with a uniform diameter and a relatively longer epiphallus (HAUSDORF 2000). There are numerous records of $M$. claustralis from western Turkey, including two localities in Bozcaada (HAUSDORF 2000) the descriptions of which match our stations Bz5 and Bz18 where we also found the species.

Monacha ocellata (Roth, 1839): We identified this species also by dissection as its shells cannot be separated from those of $M$. syriaca (Ehrenberg). The genitalia of the specimens from Bozcaada agreed with the characteristics of the genitalia of $M$. ocellata from the Karaburun Peninsula, Turkey in the south (ÖRSTAN 2014). The presence of M. ocellata in Bozcaada fits into the more northerly range of $M$. ocellata in Turkey compared to the range of M. syria$c a$, which covers south-western and southern Turkey (HAUSDORF 2000).

Orculella critica (Pfeiffer, 1856): We identified the Orculella specimens from Bozcaada as $O$. critica based on the characteristics of their male genitalia, 
especially the relatively long appendix and the attachment of the penile retractor at the junction of the penis, epiphallus and flagellum (Fig. 11). In the conchologically similar $O$. ignorata, a species widespread in western Turkey, the appendix is much shorter and the penile retractor attaches on the penis (HAUSDORF 1996, GitTENBERGER \& HAUSDORF 2004). O. criti$c a$ is common in Greece, but it has so far been recorded from only a few localities in western Turkey (HAUSDORF 1996). SCHÜTT (2010) reported it from Bozcaada, but the original source of that record is not known.

Helix nucula Mousson, 1854: There are three relatively small and similar looking Helix species in western Turkey: $H$. pomacella Mousson, $H$. figulina Rossmässler and $H$. nucula. The range of $H$. pomacella is restricted to northwest Turkey with a few records from Bulgaria, H. figulina is distributed primarily in Greece with only three published records from northwest Turkey, while $H$. nucula is common in southwest and southern Turkey (NEUBERT 2014). Their anatomical differences notwithstanding, in our experience the shells of $H$. pomacella and $H$. figulina cannot be distinguished from each other reliably, but the shells of $H$. nucula differ from those of the two former species in the presence of distinct spiral incisions on the teleoconch that cross the fine radial ribs and thereby result in the formation of a granulated or beaded sculpture on the shell surface (NEUBERT 2014). Because a similar sculpture is present on the surfaces of the small Helix shells from Bozcaada (Figs 13-14), we have identified the Bozcaada shells as $H$. nucula. This is the northernmost occurrence of the species in Turkey (NEUBERT 2014: fig. 241).

Oxychilus cyprius (Pfeiffer, 1847) and Mediterranea depressa (Sterki, 1880): Several oxychilid shells were collected at station Bz3. The grouping of the shells according to their umbilicus diameters and spire heights indicated the presence of two species. A number of live collected specimens were available in the first group and the characteristics of their genitalia (Fig. 12) agreed with those of O. cyprius (RIEDEL 1991). The shells in the second group, with diameters of 7.1 and $7.3 \mathrm{~mm}$ and $\sim 4.5$ whorls, had smaller umbilici and flatter spires, but no live specimens were available. Therefore, to identify them we compared them with several oxychilid species that are likely to be present in the general area. We eliminated M. hydatina and M. inopinata (Uličný), because both species have smaller shells; Schistophallus samius (Martens) was also eliminated, because its shells with the same number of whorls are much larger than our specimens. Two species from the Istanbul area that we considered, S. investigatus Riedel and

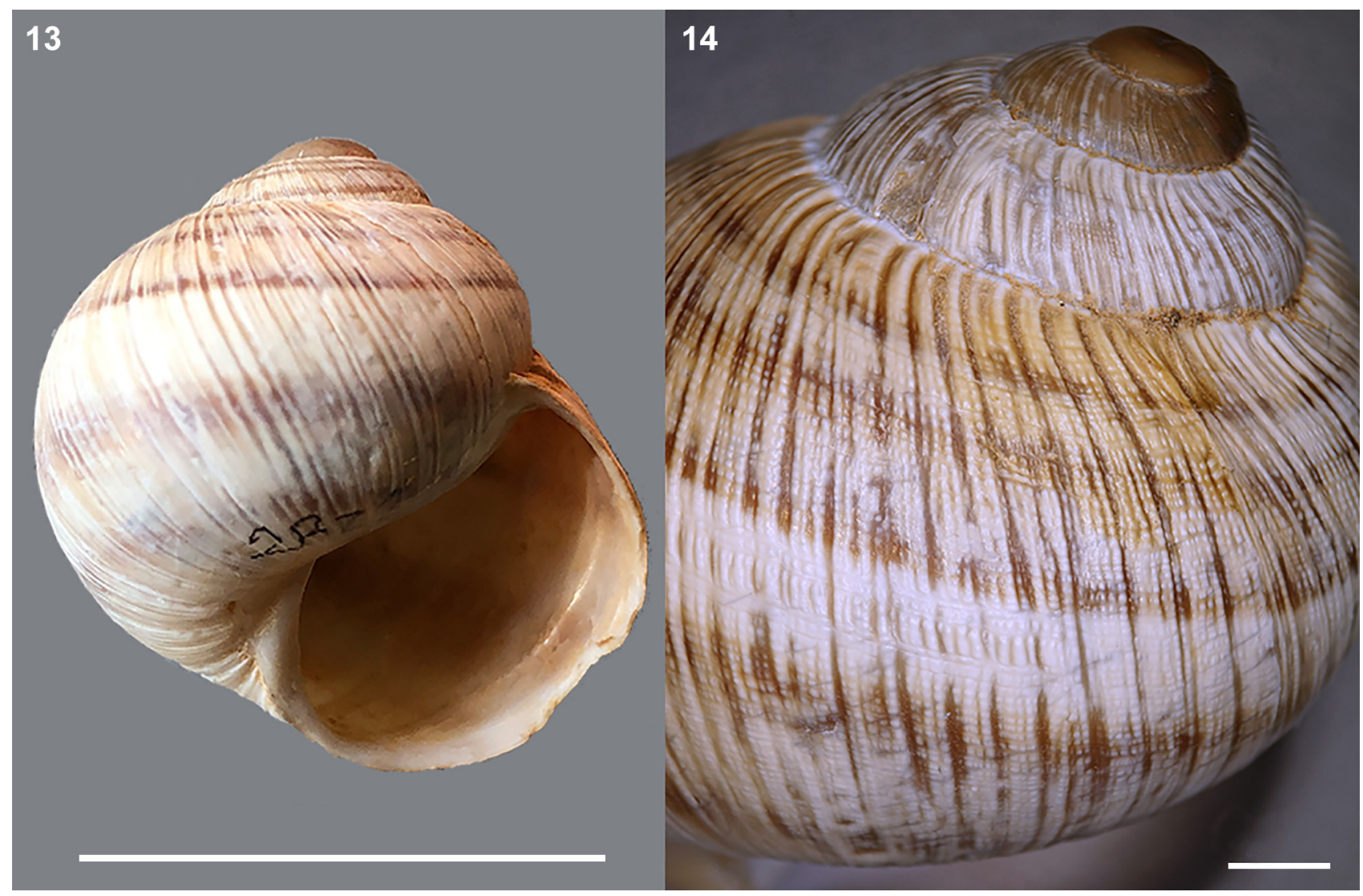

Figs 13-14. Helix nucula from Bozcaada: 13 - shell, 14 - shell surface sculpture of radial ribs crossed by incised spirals. Scale bars $20 \mathrm{~mm}(13)$ and $2 \mathrm{~mm}(14)$ 


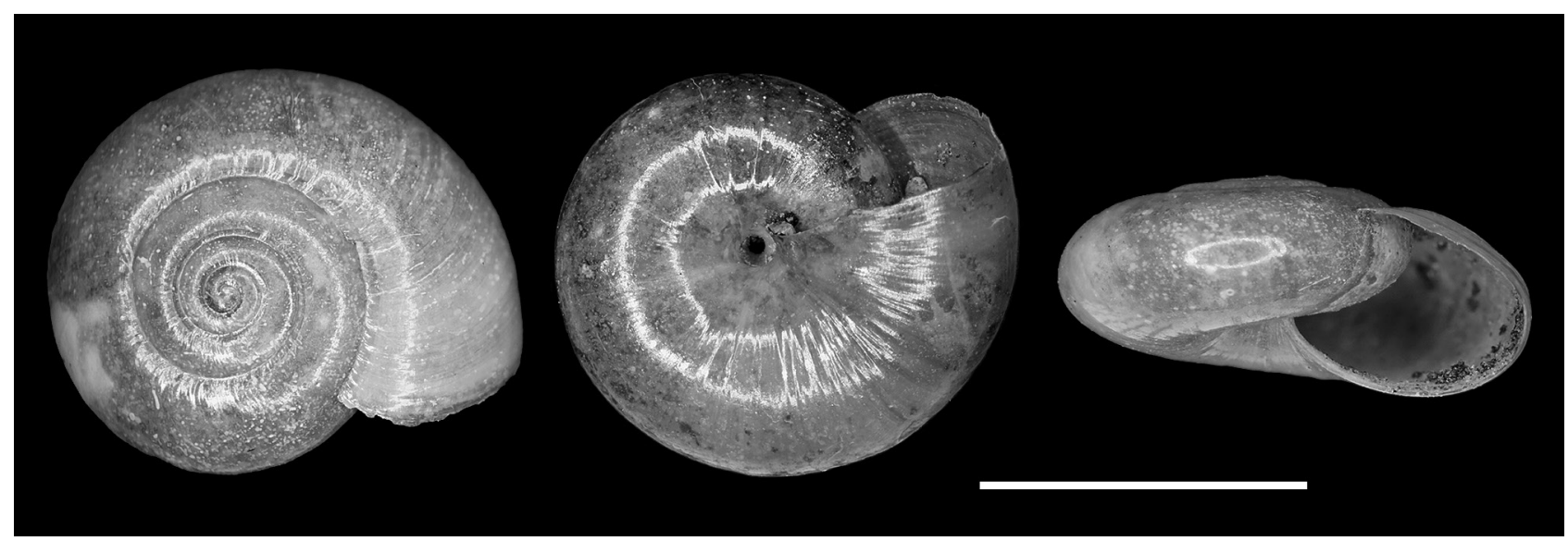

Fig. 15. Mediterranea depressa from Bozcaada. Scale bar $5 \mathrm{~mm}$

the conchologically similar Morlina moussoni (Kobelt), have fine spiral lines on their shells that are missing in our specimens. Finally, we compared our specimens with Morlina glabra (Rossmässler) and $M$. depressa. These two species have not been recorded in Turkey before (SCHÜTT 2010), but both have been found in northeastern Greece (RIEDEL 1992). The shells of M. glabra are slightly larger than our specimens and have an umbilicus that is slightly eccentric at the body whorl (KERNEY \& CAMERON 1979). On the other hand, the dimensions and the very narrow umbilicus of our specimens fit the description of M. depressa (KERNEY \& CAMERON 1979, WeLterSCHULTES 2012). Therefore, we have identified our specimens as M. depressa (Fig. 15). This constitutes the first record of this species from Turkey.

Vitrea riedeli (Damjanov et Pintér, 1969): To identify the Vitrea shells collected at stations Bz5 and Bz17, we compared them with several Vitrea species that have been recorded from the mainland Turkey and from the nearby Greek islands (RIEDEL 1992, 1995), but initially failed to find a satisfactory match. For example, $V$. schuetti Pintér, which REISCHÜTZ (1986) found on the island of Limnos, is considerably larger (PINTÉR 1972) and V. thasia Riedel et
Reischütz from the northwest island of Thasos is also larger and has a wider umbilicus than do our specimens (REISCHÜTZ 1983). On the other hand, $V$. pygmaea (Boettger) which is said to be widespread in Turkey (RIEDEL 1995, SCHÜTT 2010), is smaller and has a more eccentric umbilicus. We also considered $V$. riedeli as a possibility, but could not make a definite determination using the description and figures reproduced from the original description in PINTÉR (1972). Only after we compared our specimens with the photographs of the holotype and two paratypes of $V$. riedeli did we identify them as that species (Fig. 16). However, we note that there are slight differences between our specimens and $V$. riedeli. The largest shell we found was $2.36 \mathrm{~mm}$ in diameter, whereas PINTÉR (1972) gave the diameter range of $V$. riedeli as $2.6-3.0 \mathrm{~mm}$. Also, the sutures of our specimens appeared slightly deeper than those of $V$. riedeli and in frontal view our specimens had round profiles, but the types of $V$. riedeli had slightly shouldered profiles.

Additionally, we identified as Vitrea contracta (Westerlund, 1871) two juvenile shells from station Bz16 that had umbilici narrower than those of juvenile $V$. riedeli.

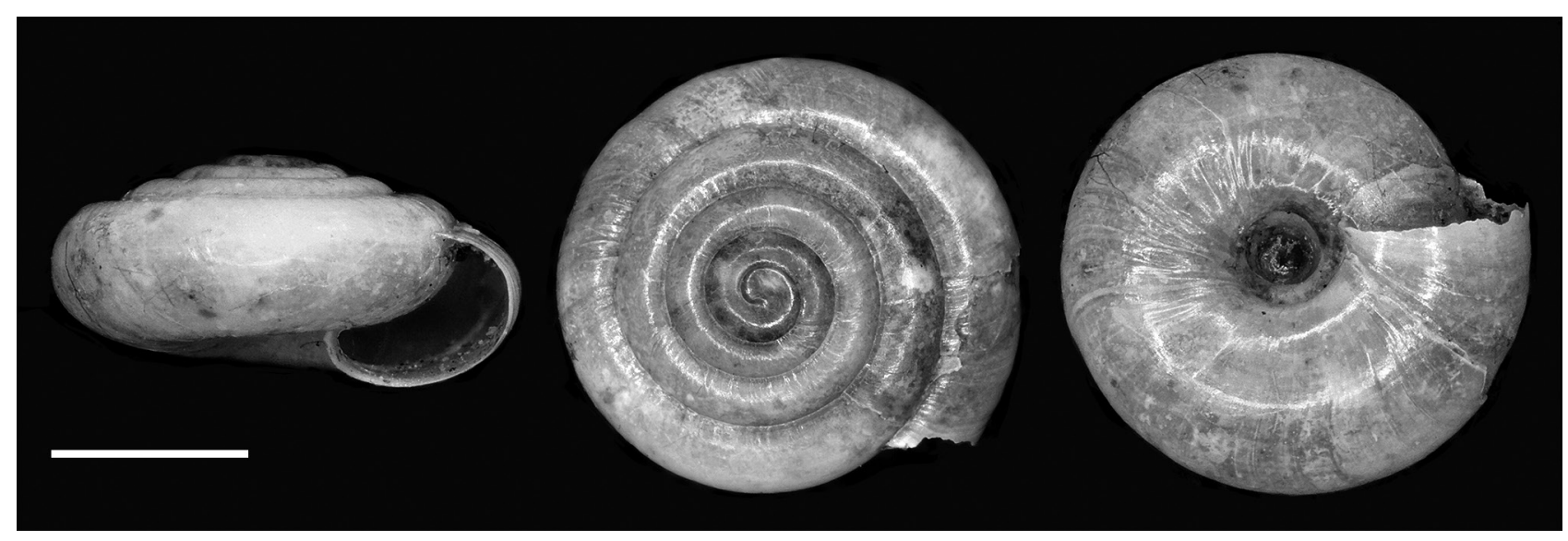

Fig. 16. Largest shell of Vitrea riedeli from Bozcaada (diameter, $2.36 \mathrm{~mm}$ ). Scale bar $1 \mathrm{~mm}$ 


\section{DISCUSSION}

According to the compilation of WELTERSCHULTES \& WiLLIAMS (1999), the number of total and native land snail species on four Aegean islands with areas $32-41 \mathrm{~km}^{2}$ and with calcareous rocks covering more than half of the island area ranged from 22 to 29 and from 15 to 21 , respectively. In comparison, Bozcaada $\left(37 \mathrm{~km}^{2}\right)$ has slightly higher total number and number of native land snail species. On the other hand, the land snail species-area equation derived by TRIANTIS et al. (2005: equation 1a) for the Skyros archipelago (also in the Aegean Sea) predicted the number of species for Bozcaada as 29.7, which is in exact agreement with our total.

Bozcaada is separated from the coast of Turkey by a distance of about $5 \mathrm{~km}$, from the island of Gökçeada in the north by about $35 \mathrm{~km}$ and from the island of Limnos in the west by about $50 \mathrm{~km}$. The depth of the sea between Bozcaada and the mainland Turkey does not exceed $30 \mathrm{~m}$ and within the span of the triangle formed by the opposite coasts of Bozcaada, Gökçeada and Limnos, the depth is above $90 \mathrm{~m}$ (NCEI 2022). These distances and depths imply that during the Last Glacial Maximum about 21,000 years ago when the worldwide sea level may have been as much as $130 \mathrm{~m}$ below its present level (CLARK \& MIX 2002), land connections must have existed between Gökçeada, Limnos, Bozcaada and the coastal areas of Turkey. Therefore, some continuity of the native land snail faunas of Turkey, Bozcaada, Gökçeada and Limnos would be expected.

No systematic survey of the land snail fauna of the region of Turkey facing Bozcaada has been published, although several isolated records exist from around Çanakkale in the north and from inland areas east of Bozcaada. Nor is there a published land snail survey of Gökçeada, but a few records from that island have also appeared in the literature.

The type locality of $M$. liebegottae is Gökçeada (HAUSDORF 2000). We have so far not found M. liebegottae on Bozcaada. The description of that species suggests that its shells would be difficult to distinguish from those of $M$. claustralis. As indicated above, we identified the two specimens from our station $\mathrm{Bz} 2$ that we dissected as $M$. claustralis and subsequently, identified several empty and similar looking shells from elsewhere on the island as the same species. However, some of those empty shells may be M. liebegottae.

REISCHÜTZ (1986) published a list of the land snails of Limnos. Of the 29 land snail taxa (excluding slugs) to which REISCHÜTZ (1986) gave full names, 15 were also found on Bozcaada. We will discuss only a few of those species here. The species REISCHÜTZ (1986) recorded as Sphyradium doliolum turcica (Letourneux) was probably Orculella critica (see HAUSDORF 1996: 17), which we identified by dissec- tion. Metafruticicola pellita (Férussac), a species with a distinct coloured band on its shell, has been recorded from both Limnos and Gökçeada (BANK et al. 2013), but is missing on Bozcaada. Likewise, both Monacha rothii (Pfeiffer) and Lindholmiola lens (Férussac) were widespread on Limnos, but neither species was found on Bozcaada. On the other hand, Pseudojaminia seductilis, a species widespread on Bozcaada, and A. discolor, present at several localities on Bozcaada, were both absent on Limnos. Some of these differences in the land snail faunas of these three islands may have resulted from independent introductions by humans, while other differences may have resulted from local extinctions of some species perhaps due to slight differences in the environmental conditions.

Another island we may consider is Samothraki, which is located about $75 \mathrm{~km}$ northwest of Bozcaada. A total of 27 land snail species have been recorded from Samothraki (REISCHÜTZ 1986, 1988, GEORGIEV \& STOYCHEVA 2010). An exact correspondence of the species names given for Samothraki and Bozcaada is not possible because of the presence of species with somewhat uncertain identifications (for example, Truncatellina species). We estimate that about 10 widespread species recorded on Samothraki were also found on Bozcaada. What is noteworthy is the presence on Samothraki of several species, including two clausiliids (Idyla and Bulgarica species) and the endemic Vitrea schneideri Riedel et Reischütz, that are absent on Bozcaada. One possible explanation for these faunal differences is the location of the North Aegean Trough between Samothraki in the north and Gökçeada and Limnos in the south. Along the North Aegean Trough the depth of the sea exceeds $800 \mathrm{~m}$ between Samothraki and Gökçeada and 1,000 m between Samothraki and Limnos (NCEI 2022). These depths indicate that Samothraki was not connected to the land mass formed by Bozcaada, Gökçeada and Limnos during the Last Glacial Maximum. Therefore, no active dispersal of land snails could have taken place between the discussed islands.

\section{ACKNOWLEDGEMENTS}

We thank RUUd BANK, ONDŘEJ KORÁBEK, EIKE NEUBERT, BARNA PÁll-Gergely and Francisco WELTER-SCHULTES for offering their opinions on the identities of some of our specimens and TIM PEARCE for an informal review of the manuscript. EIKE NeUBERT and BARNA PÁLL-GERGELY provided photographs of the type specimens of $V$. riedeli that made it possible for us to identify our specimens. The first author also acknowledges the companionship of his wife BEYSUN during two trips to Bozcaada. 


\section{REFERENCES}

ACIOĞLU Y. 2015. Çanakkale'deki Osmanlı Kaleleri. Çanakkale Araştırmaları Türk Yıllığı 13: 93-122. http://acikerisim.lib.comu.edu.tr:8080/xmlui/handle/ COMU/1374

ANONYMOUS 1916. Mediterranean Pilot. Vol. 4. Government Printing Office, Washington, pp. 383-384.

BANK R. A. 1985. Eine neue Enide von der griechischen Insel Mytilini (Gastropoda: Pupillacea). Heldia 1: 41-44.

BANK R. A., GitTENBERGER E., NEUbert E. 2013. Radiation of an eastern Mediterranean landsnail genus: revision of the taxa belonging to Metafruticicola von Ihering 1892 (Gastropoda, Pulmonata: Hygromiidae). Archiv für Molluskenkunde 142: 67-136.

https://doi.org/10.1127/arch.moll/1869-0963/142/ 067-136

BouRGUignAT J. R. 1855. Aménités malacologiques. Revue et Magasin de Zoologie pure et appliquée 7: 556-574.

Clark P. U., MiX A. C. 2002. Ice sheets and sea level of the Last Glacial Maximum. Quaternary Science Reviews 21: 1-7. https://doi.org/10.1016/S0277-3791(01)00118-4

ERGUVANLI K. 1955. Etude geologique de l'ile de Bozcaada. Bulletin de la Société Géologique de France. S6-V: 399401.

https://doi.org/10.2113/gssgfbull.S6-V.4-6.399

FORCART L. 1940. Monographie der türkischen Enidae (Moll., Pulm.). Verhandlungen der Naturforschenden Gesellschaft in Basel 51: 106-263.

GeOrGiev D., StoycheVA S. 2010. Notes on the ecology and species diversity of the inland molluscs of Samothraki Island (North-Eastern Greece). NorthWestern Journal of Zoology 6: 71-78.

GitTEnBerger E., HAUSDORF B. 2004. The Orculella species of the South Aegean island arc, a neglected radiation (Gastropoda, Pulmonata, Orculidae). Basteria 68: 93-124.

GÜMÜş B. A., NEUBERT E. 2012. New taxa of terrestrial molluscs from Turkey (Gastropoda, Pristilomatidae, Enidae, Hygromiidae, Helicidae). ZooKeys 171: 17-37. https://doi.org/10.3897/zookeys.171.2273

HAUSDORF B. 1996. Die Orculidae Asiens (Gastropoda: Stylommatophora). Archiv für Molluskenkunde 125: $1-86$.

https://doi.org/10.1127/arch.moll/125/1996/1

HAUSDORF B. 2000. The genus Monacha in Turkey. Archiv für Molluskenkunde 128: 61-151. https://doi.org/10.1127/arch.moll/128/2000/61

HAUSDORF B. 2001. The genus Ena in Turkey, with remarks on its phylogenetic relationships (Gastropoda: Buliminidae). Journal of Natural History 35: 16271638.

https://doi.org/10.1080/002229301317092360

Kerney M. P., CAmeron R. A. D. 1979. A field guide to the land snails of Britain and North-west Europe. Collins, London.
NCEI (National Centers for Environmental Information) 2022. Bathymetric Data Viewer. Available online at https://www.ncei.noaa.gov/maps/bathymetry (accessed 23 January 2022).

MolluscaBASE 2021. MolluscaBase. Available online at https://molluscabase.org (accessed 31 December 2021).

NEUBERT E. 2014. Revision of Helix Linnaeus, 1758 in its eastern Mediterranean distribution area, and reassignment of Helix godetiana Kobelt, 1878 to Maltzanella Hesse, 1917 (Gastropoda, Pulmonata, Helicidae). Contributions to Natural History 26: 1-200.

NORDSIECK H. 1999. Annotated check-list of the species of the Albinaria-Isabellaria group (Gastropoda: Stylommatophora: Clausiliidae). Mitteilungen der Deutschen Malakozoologischen Gesellschaft 62/63: $1-21$.

ÖRSTAN A. 2001. A preliminary survey of Albinaria populations around Kuşadasi Bay, Turkey. Triton 4: 42-44.

ÖRSTAN A. 2014. A survey of the land snails of the Karaburun peninsula, Turkey. Folia Malacologica 22: 201-207.

https://doi.org/10.12657/folmal.022.014

ÖRSTAN A., YILDIRIM M. Z. 2004. Borlumastus gen. nov. (Gastropoda, Pulmonata, Enidae), a new land snail genus from Turkey. Basteria 68: 125-129.

PIEŃKOWSKA J. R., PROĆKÓW M., GÓRKA M., LESICKIA. 2018. Distribution of Monacha claustralis (Rossmässler, 1834) and M. cartusiana (O. F. Müller, 1774) (Eupulmonata: Hygromiidae) in central European and Balkan countries: new data. Folia Malacologica 26: 103-120. https://doi.org/10.12657/folmal.026.009

PINTÉR L. 1972. Die Gattung Vitrea Fitzinger, 1833 in den Balkanländern (Gastropoda: Zonitidae). Annales Zoologici 29: 210-315.

REISCHÜTZ P. L. 1983. Ein Beitrag zur Molluskenfauna der Insel Thasos. Annalen des Naturhistorischen Museums in Wien 85B: 133-146.

REISCHÜTZ P. L. 1986. Beiträge zur Molluskenfauna der Ägäischen Inseln. Malakologische Abhandlungen 11: 93-101.

REISCHÜTZ P. L. 1988. Beiträge zur Molluskenfauna Thrakiens und Ostmakedoniens, II. Annalen des Naturhistorischen Museums in Wien 90B: 341-356.

RIEDEL A. 1991. Zonitidae und Daudebardiidae von Zypern (Gastropoda, Stylommatophora). Malakologische Abhandlungen 15: 101-110.

RIEDEL A. 1992. The Zonitidae (sensu lato) (Gastropoda, Pulmonata) of Greece. Fauna Graeciae. Vol. 5. Athens.

RIEDEL A. 1995. Zonitidae sensu lato (Gastropoda, Stylommatophora) der Türkei. Übersicht der Arten. Fragmenta Faunistica 38: 1-86. https://doi.org/10.3161/00159301FF1995.38.1

SCHILEYKO A. A. 1998. Treatise on recent terrestrial pulmonate molluscs. Part 2. Gastrocoptidae, Hypselo- 
stomatidae, Vertiginidae, Truncatellinidae, Pachnodidae, Enidae, Sagdidae. Ruthenica, Supplement 2: 129-261.

SCHÜTT H. 2010. Turkish land snails. Verlag Natur \& Wissenschaft, Solingen.

Triantis K. A., Mylonas M., Weiser M. D., LiKa K., VARDINOYANNIS K. 2005. Species richness, environmental heterogeneity and area: a case study based on land snails in Skyros archipelago (Aegean Sea, Greece). Journal of Biogeography 32: 1727-1735.

https://doi.org/10.1111/j.1365-2699.2005.01322.x
WELTER-SCHULTES F. W. 2012. European non-marine molluscs, a guide for species identification. Planet Poster Edition, Göttingen.

Welter-SChUltes F. W., WiLliams M. R. 1999. History, island area and habitat availability determine land snail species richness of Aegean islands. Journal of Biogeography 26: 239-249.

https://doi.org/10.1046/j.1365-2699.1999.00276.x

Received: January 30th, 2022

Revised: February 17th, 2022

Accepted: February 19th, 2022

Published on-line: March 5th, 2022 